\title{
The role of typology and formal similarity in third language acquisition (German and Spanish)
}

\author{
Nikolina Božinović \\ nikolina.bozinovic@croatia.rit.edu \\ Rochester Institute of Technology Croatia \\ Barbara Perić \\ barbara.peric@croatia.rit.edu \\ Rochester Institute of Technology Croatia
}

The focus of this study is the role of previously acquired languages in the acquisition of a third language (L3). It is focused on cross-linguistic influences (CLI) in German/Spanish third language acquisition (TLA) by learners with Croatian first language (L1) and English second language (L2). Participants in this study were third-year undergraduate students at Rochester Institute of Technology's subsidiary in Croatia (RIT Croatia). All the participants had exclusively Croatian as L1, English as L2, and were learning German and Spanish as L3 at the time of the study. The present study investigates the relationship between language typology and formal similarity and transfer/error production, since many studies have demonstrated that typology plays a determining role in cross-linguistic transfer (Cenoz, Hufeisen \& Jessner 2001; Hammarberg 2001; Rothman 2010). There are various areas of similarity and dissimilarity between Croatian, English, German, and Spanish. A significant portion of English vocabulary comes from Romance and Latinate sources. Due to these facts, we argue that the strongest L2 (English) influence will be found in the area of lexicon. On the other hand, Croatian, German, and Spanish are more similar in the area of morphology, due to the fact that these languages have a higher degree of inflection than English. Accordingly, we argue that the strongest L1 (Croatian) influence will be found in the area of morphology. The results of 
this research confirmed our initial hypothesis that the type of transfer episodes observed may be related to language typology and formal similarity between specific features of languages. Similarities at the level of lexis and grammar between L2 English and L3 German and Spanish can influence the acquisition process of German and Spanish.

Keywords: third language acquisition, cross-linguistic influences, language typology, formal similarity

\section{INTRODUCTION}

Third language acquisition is a relatively new area of research that has expanded rapidly in recent years. Many researchers have taken the position that third language acquisition (TLA) is simply another case of adult second language acquisition (SLA) and differences between SLA and TLA have been neglected in SLA research and in studies on bilingualism. Recent research has made clear that interlanguage development of an L2 is not necessarily identical to that of an L3, especially with regard to potential sources of transfer (Cenoz, Hufeisen \& Jessner, 2001; Cenoz, 2003; Leung, 2005; Rothman \& Cabrelli Amaro, 2010). Our study is situated within the field of TLA and thus looks at learners who have acquired a second language (L2) - English - in the past and are presently in the process of acquiring a third language (L3) - German or Spanish.

Cross-linguistic influence (CLI), although defined as a field of study concerned with native and non-native language influence, has traditionally focused on L1 influence and L2 learner behavior. According to De Angelis (2007), a comprehensive theory of CLI cannot, however, be based on L1 influence alone, as a wide range of phenomena would inevitably remain unexplored and unexplained. Multilinguals have knowledge of more than two languages by definition, so the possible sources of influence automatically increase with the number of languages the individual is familiar with. The purpose of the study is to examine Croatian and English CLI.

\section{THE STUDY OF CROSS-LINGUISTIC INFLUENCES}

As De Angelis (2007) points out, the study of cross-linguistic influences seeks to explain how, and under which conditions, previously acquired linguistic knowledge influences the production, understanding, and development of the target language. The term cross-linguistic influences was initially proposed by Sharwood Smith and Kellerman for phenomena concerning 
"the interplay between earlier and later acquired languages" (1986: 1, as cited in Bayona, 2009: 11). As Bayona (2009) states, prior to the publication of Sharwood Smith and Kellerman, CLI had traditionally been studied following the methodology of error analysis (EA) (Lado, 1957; Corder, 1967).

Our study focuses on errors that are clearly traceable to previously acquired languages, leaving aside those errors that are not connected with CLI. Researchers have recently established a number of detailed classifications of the type of errors found in L3 production (James, 1998; Bouvy, 2000; Ringbom, 2001; Celaya \& Torras, 2001). Our study opts for employing Bouvy's classification but including some necessary modifications required specifically for the examination of our corpus.

Cross-linguistic influences seem to be particularly important in providing explanations about the roles of the different languages that come into play during the third or additional language acquisition process. The question of transfer between and among the languages involved in third- or additional-language acquisition is very important. Early studies proved that language typology and linguistic distance influence cross-linguistic transfer (Ringbom, 1987; Singleton, 1987). While the first language was originally considered the main source of transfer in the process of acquisition of further languages, Hammarberg (2010) stated that other languages could be more dominant sources of transfer, and he emphasized the fact that the complexity of the multilingual learners' language background should be taken into account. Similarly, several studies (Cenoz \& Jessner, 2000; Cenoz, 2001; Hammarberg, 2001) found that the L3 learner has already acquired one second language (L2) and that this knowledge plays a role in the acquisition of other foreign languages. Williams and Hammarberg (1998) cited the following factors as being influential for the activation of a language in L3 production: typology, L2 status, proficiency, and recency. They also pointed out that the most influential factor in competing with the target language is the prior language that scores highest on all the above-mentioned determiners. Typology refers to language distance. Regarding the L2 status, Williams and Hammarberg suggest that, in the initial stage of acquisition, the L2 language is activated together with the L3 interlanguage, and that over time this role is taken over by the L3 itself. Based on L2 status (Hammarberg, 2001), L2 acts as a filter in L3 acquisition, blocking L1 transfer. Some studies dealing with L2 influences in the domain of syntax proved that L2 syntactic transfer had no impact on L3 acquisition (Dentler, 2000; Bouvy, 2000). Dentler (2000) analyzed L3 German main clauses produced by native speakers of Swedish with L2 English and found that they did not 
use the "verb-second position" rule correctly even though the same word order rule also exists in Swedish, which is not the case for English. An influential factor in the acquisition of a further language is language proficiency. Williams and Hammarberg (1998) stressed that, if learners are proficient in another language, this foreign language may play quite a different role than the native language in the subsequent acquisition of a new language. Bardel (2010) suggests that the L2 proficiency level and the L3 proficiency level have an influence on the activation of previously acquired languages, and in accordance with Bardel and Falk (2007), in order to transfer syntactic structures from L2 into L3, one needs to have a high level of proficiency in the L2. Finally, De Angelis (2007) explained the notion of recency of use, which refers to how recently the language was used. It is assumed that the most recently used other non-target language will be activated more easily.

As Grymska (2017) stated, lexical transfer is the most preferred type of transfer, because it can be easily observed; that is, when a learner uses an inappropriate word in an utterance, it can ruin the meaning of the entire sentence. Studies focusing on lexical transfer are quite numerous (Ringbom, 2005; De Angelis, 2007; Gabryś-Barker, 2005, 2006; Chlopek, 2011, Targońska, 2004), but there are fewer works on cross-linguistic influence at the morphological and orthographic level. Cross-linguistic influence occurs because the system of the target language is not acquired in a sufficient way. The research conducted by Targońska (2004) emphasized that L2 English can be helpful in learning L3 German because of the fact that students often notice similarities between these two languages.

\section{THE ROLE OF LANGUAGE TYPOLOGY}

Typology refers to language distance. Cenoz, Hufeisen and Jessner (2001) present one of the studies that suggest that the connection between the L3 and the L2 is stronger than that between the L3 and the L1, especially if the L2 and L3 are typologically related.

Rothman (2010) offered the typological primacy model (TPM), which in effect is a modification of the Cumulative Enhancement Model (Flynn, Foley \& Vinnitskaya, 2004). However, the CEM and the TPM differ in that only the latter anticipates the possibility of non-facilitative transfer based on overall typological proximity. Typological closeness has been found to be one of the most influential factors in the L3 acquisition of lexis. However, differences between languages among the same language family group can be found. For example, although English is a Germanic language at the 
lexical level, it exhibits more influences from Romance languages, and at the morpho-syntactic level, it shares few similarities with the rest of the Germanic languages (Grymska, 2017; Dentler, 2000).

According to De Angelis (2007), language distance refers to the distance that a linguist can objectively and formally define and identify between languages and language families. Sometimes the term formal similarity is also used to refer to a relationship of similarity between the features or components of two or more languages without necessarily implying a genetic relationship between them. De Angelis (2007) states that relatedness and formal similarities are important triggers of CLI. Relatedness is defined on the basis of genetic affiliation, whereby languages are said to be related or close to one another when they belong to the same family (e.g., Indo-European) or the same subgroup of a family (e.g., the Romance or Germanic subgroups within the Indo-European family). Formal similarity instead explicitly identifies the similarity between specific features or components of languages, ranging from their grammatical structures to their lexicons, phonetic features, graphic forms, and so forth. Two unrelated languages can consequently be formally similar with respect to some features or components.

\section{AIM}

This study addresses the role of previously acquired languages in the acquisition of a third language (L3). It focuses on cross-linguistic influences in German/Spanish L3 acquisition by learners with Croatian L1 and English L2. The purpose of the study is to examine Croatian and English CLI.

Our hypothesis is as follows:

The type of transfer episodes observed may be related to language typology and formal similarity between specific features or components of language.

As De Angelis (2007) states, finding evidence in favor of language closeness is relatively easy whenever speakers are familiar with a combination of related and unrelated languages and only two of these (the source and the target) are related to one another, as is the case with English and German, which belong to the Germanic group of languages. The question becomes more complex whenever learners are familiar with languages that belong to the same language family, but not to the same subgroup within that family, 
as it is the case with our other combination of languages. Croatian, English, and Spanish belong to the same language family (Indo-European languages), but not to the same subgroup within the family. With this language background, it is very hard to predict which of the languages already in the mind is most likely to become the learner's preferred source of information during the acquisition process, as it is also hard to differentiate the respective distances of English and Croatian to Spanish if the languages are to be compared as whole sets. Rather, there is a profile of closeness and distance that varies between different areas of the languages (Williams \& Hammarberg, 2009). Due to fact that English was evaluated to have a lexical similarity of $60 \%$ with German, while a significant portion of the English vocabulary comes from Romance and Latinate sources (so that Spanish and English share many cognate words as well), we argue that the strongest L2 (i.e., English) influence will be found in the area of lexicon. On the other hand, Croatian, German, and Spanish are more similar in the area of morphology due to the fact that Croatian, German, and Spanish have a higher degree of inflection than English. Therefore, we argue that the strongest L1 (i.e., Croatian) influence will be found in the area of morphology.

The basic syntax of Spanish is to a great extent typologically similar to Croatian and English, so we do not expect to find major errors in the syntax of Spanish L3. On the other hand, since the syntax of German is very complex, and therefore differs considerably from both Croatian and English, we expect to find more syntax errors in German L3.

\section{METHODOLOGY}

\subsection{Participants}

Our total sample is composed of 60 participants (30 students of Spanish L3 and 30 students of German L3), all of whom are between the ages of 21 and 29. The participants were all L1 speakers of Croatian, had learned English as a second language, and were learning German or Spanish as a third language at the time of the study. They were all enrolled in Intermediate German/Spanish course at the Rochester Institute of Technology's subsidiary in Croatia (RIT Croatia). Students enroll in Intermediate German/Spanish in their junior year after successfully passing two semesters of Beginning German/Spanish (total of 120 hours). They all stated that they had never been to a German/Spanish-speaking country and that their first contact with the German/Spanish language had been when they enrolled in the Beginning German/Spanish course. All of them are highly proficient 
in English, since they started learning English in their early childhood and since their classes at RIT are all taught in English.

\subsection{Instrument}

We used a corpus made of compositions written during the final exam. According to Bayona (2009), students' production in free composition is thought to reflect more accurately their grammatical and communicative competence. The students were already familiar with this kind of task, as it had been an obligatory part of the final exam at the end of each of the previous semesters of the same foreign language. Apart from assigning a topic, the instructor had no other intervention. The topic was related to the material presented in class.

\subsection{Procedures}

Demographic and linguistic background data were collected by means of a language profile questionnaire, which was completed by the students after the exam (see Appendix). The design of the questionnaire was based on an adaptation of an earlier version of the linguistic profile Language Experience and Proficiency Questionnaire (LEAP-Q), designed and employed by Marian et al. (2006). The students were told that the terms first, second, and third language referred to the order of acquisition of the three languages that they had learned during the course of their lives.

Data were collected from the free compositions written during the regular final exam, and the participants were all students enrolled in the Intermediate German/Spanish course at RIT Croatia, who were native speakers of Croatian with L2 English. None of the participants were allowed to use a dictionary, and they were required to write approximately 200 words within the 100 minutes allocated for the entire test. We did not exclude any individual, because they all met the criteria for the selection due to their linguistic background. First, we extracted the errors and classified them according to the possible influence from Croatian or English that might have caused them. In addition, we constructed an error analysis database with the lexical, morphological, and syntactic features that these errors exhibited in order to corroborate our hypothesis that formal similarity in different areas of language can be an important trigger for language transfer.

Our study focuses on those errors that are clearly traceable to previously acquired languages, leaving aside those errors that are independent of CLI. These transfer errors can be divided into three categories: transfer errors 
in syntax, lexicon, and morphology. What follows is a description of the error categories used to classify the CLIs detected in our corpus. As mentioned before, since we are interested mainly in errors that reflect CLIs at the lexical, morphological, or syntactic level, we categorized them according to whether the influence can be assumed to come from Croatian, from English, or from both languages. The latter are known as ambiguous items (Bayona, 2009), which occur in cases where we could not determine the exact origin of the CLI but saw the influence of both languages (e.g., the verb to love is translated as voljeti in Croatian, and it is used in the same way as in English to express two things - 'to love a person' or 'to love to do something.' In Spanish, however, the verb querer means just 'to love [someone]', whereas for the meaning 'to love to do something', the verb gustar is used. Similarly, the German verb lieben is mostly used to express 'to love [someone]' while for expressing 'to love to do something', the word gern is used, as in the phrase Ich lese gern 'I like to read'. In this case and in other similar cases we cannot be sure about the exact origin of CLI, because Croatian and English use the same form.

\section{Lexicon}

Five subcategories of errors are included here:

- Semantic extension - usual error of lexical overlap in the languages when the learner wrongly extends the meaning into another area where the overlap no longer exists, such as cases in which one Croatian/English word corresponds to two or more German/Spanish words.

He atendido $^{1}$ a una clase de español.

Target form He asistido a una clase de español.

Croatian Sudjelovao sam na satu španjolskog jezika.

English I attended a Spanish class.

Ich hoffe, er realisiert seinen Fehler bald.

Target form Ich hoffe, er erkennt seinen Fehler bald.

Croatian Nadam se da će on uskoro shvatiti svoju pogrešku.

English I hope he realizes his mistake soon.

\footnotetext{
${ }^{1}$ Bold letters are used in examples for those cross-linguistic influences on which we are currently focused.
} 
- False cognates

Another type of lexical transfer error is caused by the erroneous use of socalled false cognates. Learners assume that words which are similar in form are also similar in meaning.

No pude encontrar el éxito.

Target form No pude encontrar la salida.

Croatian Nisam mogao naći izlaz.

English I couldn't find the exit.

Ich habe ein Gift für dich.

Target form Ich habe ein Geschenk für dich.

Croatian Imam poklon za tebe.

English I have a gift for you.

In German production, the erroneous use of the English word Gift in L3 German can be observed. The word Gift exists in German, but it means 'poison'.

- Loan Translations (or calques)

These errors are the result of a direct word-for-word translation of a Croatian/English phrase or idiom. In this section, we will also include constructions that present an incorrect preposition choice which is clearly attributable to Croatian/English transfer.

\section{Soy veinte años.}

Target form Tengo veinte años.

Croatian Imam 20 godina.

English I am twenty years old.

Dorthin kann ich mit dem Bus gehen.

Target form Dorthin kann ich mit dem Bus fahren.

Croatian Tamo mogu otići autobusom.

English I can go there by bus.

Ich bereite mich für Abitur vor.

Target form Ich bereite mich auf Abitur vor. 
Croatian Pripremam se za maturu.

English I am preparing for the matura exam.

In German language compositions, transfer is also manifested in the selection of prepositions. In the phrase prepare for the matura exam, the use of the preposition for is clear evidence of the direct influence of Croatian as well as English. There are lexical-semantic deviations in both German and Spanish. The transfer of lexical elements with different meaning in L1 and L2 can be expressed as the use of literally translated words or constructs which are not used in Croatian (hence the result is pragmatic deviation). The most common cause may be the ambiguity of German words which correspond to different words in Croatian, but homonymity (lexemes with the same form but different meaning) as well. The situation is the same with the use of verbs. In English we usually say to go by bus, and learners transferred the meaning of the verb go into German, which is gehen. One problem to note is that, in German, it is more common to say mit dem Bus fahren - not mit dem Bus gehen. Grymska (2017) pointed out that the students make use of their L2 knowledge and transfer it into L3 German, on the basis of which they try to function in new linguistic situations. The consequences of this phenomenon can develop in two different directions. On one hand, it can cause misunderstanding in communication, as, for example, with the word gift because there is a big difference between having a present (English meaning) and poison (der Gift - German meaning). On the other hand, the transfer of particular structures can be very imprecise, but it can still be communicative - e.g., the erroneous form mit dem Bus gehen still means that we are travelling by bus, although the correct form is with a different verb: mit dem Bus fahren. In English, if we are preparing for a particular event, we have to use a preposition for. The German equivalent of the above-mentioned phrase is sich vorbereiten auf/für. The majority of students identified the similarity between English for and German für and used this preposition correctly (positive transfer). It is obvious that languages differ in their prepositional systems. The prepositions are hard and very complex to learn for students, and although they are small words, they carry crucial meaning. In the examples presented, they do not change the meaning of the whole utterance, but they refer to linguistic precision.

- Borrowing - also called code switching (see, e.g., James 1998) appears when the learner directly inserts an L1/L2 word into the L3 syntax.

Estoy muy sad.

Target form Estoy muy triste. 
Croatian Jako sam tužan.

English I'm very sad.

Target form Ich bin hungrig.

Croatian Gladan sam.

English I'm hungry.

- Coinage or relexification (see, e.g., Ringbom, 1983) consists of the adaption of an L1 word to the L2 orthography or morphology. In order to study this phenomenon, we tried to find adaptations of an L1/L2 word to the L3 orthography or morphology.

\section{Quise dancear.}

Target form Quise bailar.

Croatian Želio/Htio sam plesati.

English I wanted to dance.

Es jumpte schnell ins Wasser.

Target form Er sprang schnell ins Wasser.

Croatian Brzo je skočio u vodu.

English He jumped quickly into the water.

\section{Syntax}

Syntactic errors attributed to L1/L2 interference appear when the student tries to equate parts of German/Spanish constructions with Croatian/English constructions. We have classified syntactic transfer errors into three subcategories: (a) errors in word order, (b) errors of omission, and c) errors of addition.

- Word order

The students tend to invert the order of noun and modifier by following the word order of the Croatian/English parallel construction.

\section{La mayor hermana}

Target form La hermana mayor

Croatian Starija sestra

English The older sister 
Target form

Croatian

English
Ich habe das Buch meinem Freund gegeben.

Ich habe meinem Freund das Buch gegeben.

Dao sam prijatelju knjigu.

I gave the book to my friend.

- Omission

This type of syntactic transfer error is caused by the student's tendency to omit a required grammatical element in German/Spanish which is optional, or non-existant, in the Croatian/English parallel construction.

\section{Quise visitar tus primos.}

Target form Quise visitar a tus primos.

Croatian Željela sam posjetiti tvoje rođake.

English I wanted to visit your cousins.

Er kann sich nicht so tolles Auto leisten.

Target form Er kann sich nicht so ein tolles Auto leisten.

Croatian On si ne može priuštiti takav skupocjen auto.

English He can't afford such an expensive car.

- Addition

Sometimes Croatian/English constructions cause interference in corresponding German/Spanish patterns because the student transposes a compulsory Croatian/English element literally into the German/Spanish construction where that element has no correspondence.

Target form Buscaba tu casa.

Croatian Tražio sam tvoju kuću.

English I was looking for your house.

\section{Ich bin ein Berliner.}

Target form Ich bin Berliner.

Croatian Ja sam Berlinac.

English I am a Berliner.

There is clear evidence of the direct influence of English German in terms of use of indefinite articles. One example of the transfer of articles is also evident. It is notable that in the English sentence I am a Berliner, the indef- 
inite article $a$ is necessary. The German translation of this sentence is: Ich bin Berliner - without any article. It should be noted that the students used a definite or an indefinite article in a number of cases. The source of this error could be L2 English. One reason for this phenomen may be that the students have been learning English longer than German. This means that the English article system is deeply rooted in their minds and is transferred into L3 German. This type of error emphasizes the need to differentiate between article systems by using particular examples from several foreign languages.

\section{Morphology}

In data collected for this study, morphological errors attributed to transfer were classified into errors of gender and number marking.

- Nouns, articles, and adjectives in both German and Spanish agree in gender and number just as they do in Croatian, whereas English articles and adjectives are invariable for gender and number except for this and that.

$\begin{array}{ll} & \text { Mi flor favorito } \\ \text { Target form } & \text { Mi flor favorita } \\ \text { Croatian } & \text { Moj omiljeni cvijet } \\ \text { English } & \text { My favourite flower }\end{array}$

Meine Brille sind schwarz.

Target form Meine Brille ist schwarz.

Croatian Moje naočale su crne.

English My glasses are black.

Plural forms in English can be a source of error in L3 German, as is presented in the above examples. In English, after the word glasses we use a verb in plural form, e.g., My glasses are black. The equivalent of the English word glasses in German is Brille, and after Brille we use a singular verb, e.g., Meine Brille ist schwarz. German sentence Meine Brille sind schwarz is an example of negative transfer from English into German. The source of transfer can be not only L2 English, but also student's mother tongue, Croatian, because the equivalent of the word glasses in Croatian is plural and needs a verb in plural form as well. 


\section{RESULTS AND DISCUSSION}

The compositions in Spanish and German L3 provided us with an extensive corpus from which we extracted 434 tokens through error analysis, of which 195 were lexical items with cross-linguistic influence. The compositions in German L3 provided us with 238 lexical items with cross-linguistic influence. As can been seen in Table 1, in Spanish L3, L1 (Croatian) influence was the cause of $31 \%$ of all of these errors, L2 (English) influence was the cause of $43 \%$ of all the errors, and $26 \%$ were deemed ambiguous items. In German L3, L1 influence was the cause of $28 \%$ of all the errors, L2 influence was the cause of $38 \%$ of all the errors, and 34\% were deemed ambiguous items.

Table 1. Type of CLI according to origin

\begin{tabular}{c|c|c}
\hline $\begin{array}{c}\text { Type of CLI according } \\
\text { to origin }\end{array}$ & $\begin{array}{c}\text { Frequency (\%) } \\
\text { Spanish }\end{array}$ & $\begin{array}{c}\text { Frequency (\%) } \\
\text { German }\end{array}$ \\
\hline CRO CLI & $61(31 \%)$ & $68(28 \%)$ \\
\hline ENG CLI & $84(43 \%)$ & $90(38 \%)$ \\
\hline Ambiguous items & $50(26 \%)$ & $80(34 \%)$ \\
\hline Total & $195(100 \%)$ & $238(100 \%)$ \\
\hline
\end{tabular}

These errors were categorized by type of error into three main groups: lexicon, syntax, and morphology. As can been seen in Table 2, 64\% of all interference errors in Spanish L3 were committed in the area of lexicon, $11 \%$ in the area of syntax, and $25 \%$ in the area of morphology. These data indicate that 59\% of all interference errors in German L3 were committed in the area of lexicon, $18 \%$ in the area of syntax, and $23 \%$ in the area of morphology.

In order of frequency, the most common errors caused by ENG CLI have been identified within the area of lexicon, specifically those caused by adaptations of an L2 (English) word to the L3 (German, Spanish) orthography or morphology. Only 7 examples of direct borrowing from English were found in Spanish L3, and only 4 were found in German L3. The findings of this study confirm the results of previous research by Ringbom (2001, 2005) in which the errors of creativity (e.g., coinages, or calques) confirm the hypothesis that the process of language acquisition in a foreign language learner is affected by the stages in education: as learners grow older, and reach a higher level of language competence, they use less borrowings in their writing. 
The authors of this paper did not expect any major discrepancies in the area of syntax, since all three languages, Croatian, English, and Spanish, are typologically similar in terms of syntax. The results of the study have thus confirmed our hypothesis, since only $11 \%$ of the errors were identified as syntax errors. Our results also show that the most common errors that were found in writing were those caused by the omission of a required Spanish element. On the other hand, the most common syntax errors in German L3 were caused by incorrect usage of word order, which confirms our hypothesis that the strongest evidence of language transfer is in the transfer of prepositions from L2 English into L3 German. This study has shown that students mostly transfer those prepositions which are phonetically similar in the two languages (e.g., for/für) from L2 English into L3 German. Another example of transfer that was recognized in this study was the incorrect use of articles in German sentences when such usage is redundant, probably because of the stronger influence of L2 English (e.g., $I$ am a Berliner - Ich bin ein Berliner).

Table 2. Type of CLI according to typology of error

\begin{tabular}{|c|c|c|c|}
\hline $\begin{array}{l}\text { CLI according to } \\
\text { typology of error }\end{array}$ & $\begin{array}{c}\text { Subcategories } \\
\text { of errors }\end{array}$ & $\begin{array}{l}\text { Frequency } \\
\text { Spanish }\end{array}$ & $\begin{array}{c}\text { Frequency } \\
\text { German }\end{array}$ \\
\hline \multirow[t]{5}{*}{ Lexical Errors } & Semantic extension & $20(16 \%)$ & $6(4 \%)$ \\
\hline & False cognates & $5(4 \%)$ & $4(3 \%)$ \\
\hline & Calques & $53(42 \%)$ & $91(65 \%)$ \\
\hline & Code switching & $7(6 \%)$ & $4(3 \%)$ \\
\hline & Coinage & $40(32 \%)$ & $35(25 \%)$ \\
\hline $\begin{array}{l}\text { Total-Lexical } \\
\text { errors }\end{array}$ & & $\begin{array}{l}125(100 \%)-64 \% \text { out of } \\
\text { total number of errors }\end{array}$ & $\begin{array}{l}140(100 \%)-59 \% \text { out of } \\
\text { total number of errors }\end{array}$ \\
\hline \multirow[t]{3}{*}{ Syntactic errors } & Word order & $3(14 \%)$ & $30(71 \%)$ \\
\hline & Omission & $16(76 \%)$ & $8(19 \%)$ \\
\hline & Addition & $2(10 \%)$ & $4(10 \%)$ \\
\hline $\begin{array}{c}\text { Total-syntactic } \\
\text { errors }\end{array}$ & & $\begin{array}{l}21(100 \%)-11 \% \text { out of } \\
\text { total number of errors }\end{array}$ & $\begin{array}{l}42(100 \%)-18 \% \text { out of } \\
\text { total number of errors }\end{array}$ \\
\hline $\begin{array}{l}\text { Morphological } \\
\text { errors }\end{array}$ & $\begin{array}{l}\text { Gender and num- } \\
\text { ber marking }\end{array}$ & 49 (100\%) & $56(100 \%)$ \\
\hline $\begin{array}{l}\text { Total-morpholog- } \\
\text { ical errors }\end{array}$ & & $\begin{array}{l}49(100 \%)-25 \% \text { out of } \\
\text { total number of errors }\end{array}$ & $\begin{array}{l}56(100 \%)-23 \% \text { out of } \\
\text { total number of errors }\end{array}$ \\
\hline Total & & 195 (100\%) & $238(100 \%)$ \\
\hline
\end{tabular}


As indicated in Table 3, the strongest L1 (Croatian) influence is found in the area of morphology of both L3s (German and Spanish) (100\% CRO CLI), which also confirms our hypothesis that, in the area of morphology, students will rely more on Croatian in language transfer due to the morphological similarity between these three languages.

Table 3. Type of CRO CLI according to typology of error

\begin{tabular}{c|c|c}
\hline $\begin{array}{c}\text { CRO CLI according to } \\
\text { typology of error }\end{array}$ & $\begin{array}{c}\text { Frequency } \\
\text { Spanish }\end{array}$ & $\begin{array}{c}\text { Frequency } \\
\text { German }\end{array}$ \\
\hline Lexical errors & $\begin{array}{c}9(15 \%)-7 \% \text { out of total number } \\
\text { of lexical errors }\end{array}$ & $\begin{array}{c}6(9 \%)-8 \% \text { out of total number of } \\
\text { lexical errors }\end{array}$ \\
\hline Syntactic errors & $\begin{array}{c}3(5 \%)-14 \% \text { out of total number } \\
\text { of syntactic errors }\end{array}$ & $\begin{array}{c}6(9 \%)-14 \% \text { out of total number } \\
\text { of syntactic errors }\end{array}$ \\
\hline Morphological errors & $\begin{array}{c}49(80 \%)-100 \% \text { out of total } \\
\text { number of morphological errors }\end{array}$ & $\begin{array}{c}56(82 \%)-100 \% \text { out of total } \\
\text { number of morphological errors }\end{array}$ \\
\hline Total & $\mathbf{6 1}(\mathbf{1 0 0} \%)$ & $\mathbf{6 8}$ (100\%) \\
\hline
\end{tabular}

Table 4 shows that the strongest English language influence is found in the area of lexicon (66\% ENG CLI in Spanish L3 and 58\% ENG CLI in German L3). In the analysis of these results, however, one should keep in mind that 27\% (for Spanish) and 37\% (for German) of these errors are ambiguous items, as shown in Table 5 (cases in which we could not determine the exact origin of the CLI, but we saw a possible influence of either or both languages).

Table 4. Type of ENG CLI according to typology of error

\begin{tabular}{c|c|c}
\hline $\begin{array}{c}\text { ENG CLI according } \\
\text { to typology of error }\end{array}$ & $\begin{array}{c}\text { Frequency } \\
\text { Spanish }\end{array}$ & $\begin{array}{c}\text { Frequency } \\
\text { German }\end{array}$ \\
\hline Lexical errors & $\begin{array}{c}82(98 \%)-66 \% \text { out of total number } \\
\text { of lexical errors }\end{array}$ & $\begin{array}{c}82(91 \%)-58 \% \text { out of total number } \\
\text { of lexical errors }\end{array}$ \\
\hline Syntactic errors & $\begin{array}{c}2(2 \%)-10 \% \text { out of total number } \\
\text { of syntactic errors }\end{array}$ & $\begin{array}{c}8(9 \%)-19 \% \text { out of total number of } \\
\text { syntactic errors }\end{array}$ \\
\hline Morphological errors & $0(0 \%)$ & $0(0 \%)$ \\
\hline Total & $\mathbf{8 4}(\mathbf{1 0 0} \%)$ & $\mathbf{9 0 ( 1 0 0 \% )}$ \\
\hline
\end{tabular}


Table 5. Type of ENG/CRO CLI according to typology of error

\begin{tabular}{c|c|c}
\hline $\begin{array}{c}\text { ENG/CRO CLI according to } \\
\text { typology of error }\end{array}$ & $\begin{array}{c}\text { Frequency } \\
\text { Spanish }\end{array}$ & $\begin{array}{c}\text { Frequency } \\
\text { German }\end{array}$ \\
\hline Lexical errors & $\begin{array}{c}34(68 \%)-27 \% \text { out of total } \\
\text { number of lexical errors }\end{array}$ & $\begin{array}{c}52(65 \%)-37 \% \text { out of total } \\
\text { number of lexical errors }\end{array}$ \\
\hline Syntactic errors & $\begin{array}{c}16(32 \%)-76 \% \text { out of total } \\
\text { number of syntactic errors }\end{array}$ & $\begin{array}{c}28(35 \%)-12 \% \text { out of total } \\
\text { number of syntactic errors }\end{array}$ \\
\hline Morphological errors & $0(0 \%)$ & $0(0 \%)$ \\
\hline Total & $\mathbf{5 0 ( 1 0 0 \% )}$ & $\mathbf{8 0}(\mathbf{1 0 0} \%)$ \\
\hline
\end{tabular}

Our findings allow us to support De Angelis's (2007) statement that language typology and formal similarity between specific features or components of languages plays a key role in language transfer, and in our case these features/components were the lexical similarity between English and Spanish/German and the morphological similarity between Croatian and Spanish/German.

\section{CONCLUSION}

The present study has examined the production of CLI in trilingual learners, all of whom are L1 Croatian speakers and long-term L2 English speakers, and who are in the process of acquiring either German or Spanish as a third language. The results of the study confirmed our initial hypothesis that the type of transfer episodes observed may be related to language typology and formal similarity between specific features or components of a language they know and those of the language they are currently learning.

Other variables that appear to play a key role in L3 acquisition, as Hammarberg (2001) states, are the levels of proficiency and recency. In this study, the proficiency and recency factors were neutralized due to the fact that all our participants were highly proficient in L2 and had formal instruction in L2. Summarizing the above-mentioned research findings, it can be observed that similarities at the level of lexis and grammar between $\mathrm{L}$ English and L3 German and Spanish can influence the acquisition process of German and Spanish. In some examples, the transfer of a similar word does not change the meaning of the sentence very much, but this phenomenon refers to linguistic precision. Although transfer errors do occur, learners are still able to communicate and prove that they try to function not only in the new language, but also in a multilingual environment. It is a challenge for both teachers and students to be aware of the similarities 
and differences between languages that are typologically close. It is worth drawing students' attention to this problem and trying to facilitate the teaching program in order to make their speech and written production less erroneous.

Perhaps future studies that explore other variables affecting multilingual transfer under the same language pairings and provide a more detailed and contrastive qualitative analysis of each of error type would tell us more about the dynamic nature of linguistic transfer itself.

This paper did not examine the exposure that the respondents had to other foreign languages; this could be considered a possible limitation of the study, and the authors see this question as a possible direction of further research.

\section{REFERENCES}

Bayona, P. (2009) Crosslinguistic influences in the acquisition of Spanish L3: London, Ontario: UMI Dissertations Publishing.

Bardel, C. \& Falk, Y. (2007) The role of the second language in third language acquisition: The case of Germanic syntax. Second Language Research, 23, 459-484.

Bardel, C. (2010) The lexicon of advanced L2 learners: In K. Hyltenstam (Ed.) High-level proficiency in second language use. Berlin: Mouton de Gruyter.

Bouvy, C. (2000) Towards the Construction of a Theory of Cross-linguistic Transfer. In Cenoz, J. \& Jessner, U. (Eds.) English in Europe. The Acquisition of a Third language. Clevedon: Multilingual Matters, 143-156.

Celaya, M.L. \& Torras, M.R. (2001) L1 influence and EFL vocabulary: do children rely more on L1 than adult learners? Proceedings of the 25th AEDEAN Meeting (pp.1-14). Granada: University of Granada.

Cenoz, J., Hufeisen, B. \& Jessner, U. (Eds.) (2001) Cross-linguistic Influence in Third language Acquisition: Psycholinguistic Perspectives: Clevedon, UK: Multilingual Matters.

Cenoz, J. (2003) The role of typology in the organization of the multilingual lexicon. In Cenoz, J., Hufeisen, B. \& Jessner, U. (Eds.) The multilingual lexicon. Dordrecht, the Netherlands: Kluwer, 103-116.

Cenoz, J. (2001) The effect of linguistic distance, L2 status and age on cross-linguistic influence in third language acquisition. In Cenoz, J., Hufeisen, B. \& Jessner, U. (Eds.) Cross-linguistic influence in Third Language Acquisition: Transfer Phenomena of L2 (German) Lexical and Syntactic Properties. 39 Psycholinguistic perspectives. Clevedon, Multilingual Matters, 8-19.

Cenoz, J. \& Jessner, U. (2000) English in Europe. The Acquisition of a Third Language. Clevedon: Multilingual Matters.

Corder, S. (1967) The significance of learners' errors. International Review of Applied Linguistics, 5, 161-170.

De Angelis, G. (2007) Third or additional language acquisition. Clevedon, Multilingual Matters. 
Dentler, S. (2000) Deutsch und English - das gibt immer Krieg. In Dentler, S., Hufeisen, B. \& Lindemann, B. (Eds.) Tertiär- und Drittsprachen: Projekte und empirische Untersuchungen. Tübingen: Stauffenburg Verlag, 77-97.

Flynn, S., Foley, C. \& Vinnitskaya, I. (2004) The cumulative-enhancement model for language acquisition: Comparing adults' and children's patterns of development in first, second and third language acquisition. International Journal of Multilingualism, 1, 3-17.

Gabryś-Barker, D. (2006) The interaction of languages in the lexical search of multilingual language users. In Arabski, J. (Ed.) Cross-linguistic influences in the second language lexicon. Clevedon: Multilingual Matters, 144-166.

Gabryś-Barker, D. (2005) Aspects of Multilingual Storage, Processing and Retrieval. Katowice: Wydawnictwo Uniwersytetu Śląskiego.

Grymska, B. (2017) The Influence of L2 English on learning of L3 German structures different examples of cross-linguistic influence. English Insights, 1.

Hammarberg, B. (2001) Roles of L1 and L2 in L3 Production and Acquisition. In Cenoz, J., Hufeisen, B., \& Jessner, U. (Eds.) Cross-linguistic Influence in Third Language Acquisition: Psycholinguistic Perspectives. Clevedon: Multilingual Matters, 21-41.

Hammarberg, B. (2010) The languages of the multilingual: Some conceptual and terminological issues. IRAL - International Review of Applied Linguistics in Language Teaching, 48 (2-3), 91-104.

James, C. (1998) Errors in Language Learning and Use: Exploring Error Analysis. London: Longman.

Lado, R. (1957) Linguistic Across Cultures. Ann Arbor: University of Michigan Press.

Leung, Y.-K. I. (2005). L2 vs. L3 initial state: A comparative study of the acquisition of French DPs by Vietnamese monolinguals and Cantonese-English bilinguals. Bilingualism: Language and Cognition, 8 (1), 39-61.

Marian, V., Blumenfeld, H. \& Kaushanskaya, M. (2006) The Language Experience and Proficiency Questionnaire (OLEAP-Q): Assessing Language Profiles in Bilinguals and Multilinguals. Toronto: Conference on Second Language Acquisition and Multilingualism. York University.

Ringbom, H. (1983) Borrowing and lexical transfer. Applied Linguistics, 4, 207 - 212.

Ringbom, H. 1987. The role of the first language in foreign language learning. Clevedon: Multilingual Matters.

Ringbom, H. (2001) Lexical transfer in L3 production. In J. Cenoz, B. Hufeisen \& U. Jessner (Eds.) Cross-linguistic Influence in Third Language Acquisition: Psycholinguistic Perspectives. Clevedon: Multilingual Matters, 59-68.

Ringbom, H. (2005) L2 Transfer in Third Language Acquisition. In Hufeisen, B., Fouser, R.J. (Eds.) Introductory Readings in L3. Tübingen: Stauffenburg Verrlag, 71-82.

Rothman, J., \& Cabrelli Amaro, J. (2010) What variables condition syntactic transfer? A look at the L3 initial state. Second Language Research, 26, 189-218.

Rothman, J. (2010) L3 syntactic transfer selectivity and typological determinacy: The typological primacy model. Second language research, 27, 107-127.

Sharwood Smith, M. \& Kellerman, E. (1986) Crosslinguistic Influence in Second Language Acquisition: An introduction. In Kellerman, E., \& Sharwood Smith, M. (Eds.) Crosslinguistic Influence in Second Language Acquisition. New York: Pergamon Press. 
Singleton, D. 1987. Mother and other tongue influences on learner French. Studies in Second Language Acquisition, 9, 327-346.

Targońska, J. (2004) Zur Nutzung von Englischkenntnissen beim Erwerb des deutschen Wortschatzes. Eine empirische Untersuchung an polnischen Schülern, In B. Hufeisen, N. Marx (Eds.) Beim Schwedischlernen sind English und Deutsch ganzhilfsvoll. Untersuchungen zum multiplen Sprachenlernen. Forum Angewandte Linguistic, 44. Frankfurt am Main: Peter Lang, 117-136.

Williams, S. \& Hammarberg, B. (1998) Language switches in L3 production: Implications for a polyglot speaking model. Applied Linguistics, 19, 295-333.

Williams, S. \& Hammarberg, B. (2009) Language switches in L3 production: Implications for a polyglot speaking model. In Hammarberg, B. (Ed.) Processes in third language acquisition, 28.73. Edinburgh University Press. Originally 1998 in Applied Linguistics 19(3), 295-333.

\section{APPENDIX}

\section{LINGUISTIC PROFILE ${ }^{2}$}

Please select the appropriate response from the choices given:

- Croatian is my
a) First language
b) Second language
c) Third language
d) Fourth language

- English is my
a) First language
b) Second language
c) Third language
d) Fourth language

- German/Spanish is my
a) First language
b) Second language
c) Third language
d) Fourth language

Regarding your knowledge of English:

Age when you:

\begin{tabular}{l|l|l|l}
\hline Began acquiring it & Became fluent & Began reading it & Became fluent reading it \\
\hline & & & \\
\hline
\end{tabular}

Please state the number of years and months you spent in:

\begin{tabular}{l|l|l}
\hline & Years & Months \\
\hline A country where English is spoken & & \\
\hline A family where English is spoken & & \\
\hline A school where English is spoken & & \\
\hline
\end{tabular}

\footnotetext{
${ }^{2}$ Adapted from Marian et al. (2006).
} 
Regarding your knowledge of German/Spanish:

Age when you:

\begin{tabular}{l|l|l|l}
\hline Began acquiring it & Became fluent & Began reading it & Became fluent reading it \\
\hline & & & \\
\hline
\end{tabular}

Please state the number of years and months you spent in:

\begin{tabular}{l|l|l}
\hline & Years & Months \\
\hline A country where German/Spanish is spoken & & \\
\hline A family where German/Spanish is spoken & & \\
\hline A school where German/Spanish is spoken & & \\
\hline
\end{tabular}

\title{
Uloga tipologije i formalne sličnosti u usvajanju trećega jezika (njemački i španjolski)
}

\author{
Nikolina Božinović \\ nikolina.bozinovic@croatia.rit.edu \\ Rochester Institute of Technology Croatia \\ Barbara Perić \\ barbara.peric@croatia.rit.edu \\ Rochester Institute of Technology Croatia
}

U središtu pozornosti ovoga istraživanja je uloga prethodno usvojenih jezika u procesu ovladavanja trećim jezikom. Cilj je rada istražiti međujezične utjecaje prilikom usvajanja njemačkog/španjolskog kao trećega jezika (L3) kod učenika kojima je hrvatski prvi/materinski jezik (L1), a engleski drugi jezik (L2). Istraživanje je provedeno na uzorku od 60 ispitanika koji su polaznici treće godine Rochester instituta za tehnologiju (RIT Croatia). Svi ispitanici bili su izvorni govornici hrvatskoga jezika kojima je engleski bio drugi strani jezik, a u vrijeme istraživanja učili su njemački i španjolski kao treći strani jezik. Ovaj rad istražuje odnos jezične tipologije i formalne sličnosti te prijenosa i proizvodnje pogrešaka, što je u skladu s provedenim istraživanjima koja ukazuju da tipologija ima ključnu ulogu u međujezičnom prijenosu (Cenoz, Hufeisen i Jessner 2001; Hammarberg 2001; Rothman 2010). Postoje različita područja sličnosti i različitosti između hrvatskoga, engleskoga, njemačkoga i španjolskoga jezika. Značajan udio engleskog vokabulara upravo potječe iz romanskih i latinskih izvora, dok španjolski i engleski također dijele brojne srodne riječi. U skladu s navedenim 
činjenicama držimo da će najjači utjecaj engleskog jezika (L2) biti upravo u području leksika. S druge strane, hrvatski, njemački i španjolski ukazuju na veće sličnosti u području morfologije budući da hrvatski, njemački i španjolski imaju veći stupanj fleksije u usporedbi s engleskim jezikom. U skladu s navedenim pretpostavkama držimo da će najsnažniji utjecaj hrvatskoga jezika (L1) biti upravo u području morfologije. Rezultati istraživanja potvrdili su našu inicijalnu hipotezu da se vrsta promatranog transfera može dovesti u vezu s jezičnom tipologijom i formalnom sličnosti među specifičnim obilježjima jezika. Sličnosti u području leksika i gramatike između engleskog (L2) te njemačkog i španjolskog (L3) mogu olakšati proces usvajanja njemačkog i španjolskog jezika.

Ključne riječi: usvajanje trećega jezika, međujezični utjecaji, jezična tipologija, formalna sličnost. 